\title{
A review of observed and projected changes in climate for the islands in the Caribbean
}

\author{
A. V. KARMALKAR \\ School of Geography and the Environment, South Parks Road, University of Oxford, \\ Oxford OX1 3QY, UK. \\ Corresponding author; email: ambarish.karmalkar@metoffice.gov.uk \\ M. A. TAYLOR, J. CAMPBELL and T. STEPHENSON \\ Climate Studies Group Mona, Department of Physics, University of the West Indies, Mona, Jamaica.

\begin{abstract}
M. NEW
School of Geography and the Environment, South Parks Road, University of Oxford, Oxford OX1 3QY, UK/African Climate and Development Initiative, University of Cape Town, South Africa.
\end{abstract} \\ A. CENTELLA and A. BENZANILLA \\ Instituto de Meteorología de la República de Cuba, Habana 17, Cuba. \\ J. CHARLERY \\ Department of Computer Science, Mathematics and Physics, University of the West Indies, \\ Cave Hill, Barbados.
}

Received October 3, 2012; accepted October 30, 2012

\begin{abstract}
RESUMEN
Los cambios climáticos observados y proyectados tienen implicaciones socioeconómicas importantes para las islas del Caribe. El objetivo de este artículo es presentar información esencial sobre el cambio climático — basada en estudios previos, observaciones disponibles y simulaciones de modelos climáticos-a escalas espaciales relevantes para las islas caribeñas. Se utilizan datos del modelo general de circulación (GCM) incluidos en el Proyecto de Comparación de Modelos Acoplados fase 3 (CMIP3), así como del modelo climático regional (RCM) del Centro Hadley del Reino Unido, para aportar tanto información actual como información basada en proyecciones sobre precipitaciones y temperatura en estados insulares específicos. Se utilizan observaciones reticuladas de estaciones y datos satelitales para estudiar el clima del siglo XX y evaluar el desempeño de los modelos climáticos. Con un enfoque centrado en la precipitación, también se analizan factores como la temperatura superficial del mar, la presión al nivel del mar y los vientos que influyen en las variaciones estacionales de la precipitación. La media del ensamble del CMIP3 y el RCM captan satisfactoriamente las peculiaridades de la circulación atmosférica de gran escala en la región, pero no así el ciclo estacional bimodal característico de la precipitación. La aridez en épocas de lluvias prevista en escenarios de cambio climático en la región se ha abordado en estudios previos, pero la magnitud de la variación es muy incierta en las simulaciones tanto del GCM como del RCM. La
\end{abstract}


disminución proyectada es mayor al inicio de la temporada de lluvias y suprime la sequía del medio verano en el Caribe occidental. Las simulaciones del RCM muestran avances respecto del GCM, sobre todo por sus mejores representaciones de la extensión territorial, pero su desempeño depende en gran medida de la conducción del GCM. El presente estudio destaca la necesidad de contar con observaciones de alta resolución y comparar simulaciones de modelos climáticos para entender a fondo el cambio climático y su impacto en las pequeñas islas del Caribe.

\begin{abstract}
Observed and projected changes in climate have serious socio-economic implications for the Caribbean islands. This article attempts to present basic climate change information-based on previous studies, available observations and climate model simulations - at spatial scales relevant for islands in the Caribbean. We use the General Circulation Model (GCM) data included in the Coupled Model Intercomparison Project phase 3 (CMIP3) and the UK Hadley Centre regional climate model (RCM) data to provide both present-day and scenario-based future information on precipitation and temperature for individual island states. Gridded station observations and satellite data are used to study 20th century climate and to assess the performance of climate models. With main focus on precipitation, we also discuss factors such as sea surface temperature, sea level pressure and winds that affect seasonal variations in precipitation. The CMIP3 ensemble mean and the RCM successfully capture the large-scale atmospheric circulation features in the region, but show difficulty in capturing the characteristic bimodal seasonal cycle of precipitation. Future drying during the wet season in this region under climate change scenarios has been noted in previous studies, but the magnitude of change is highly uncertain in both GCM and RCM simulations. The projected decrease is more prominent in the early wet season erasing the mid-summer drought feature in the western Caribbean. The RCM simulations show improvements over the GCM mainly due to better representation of landmass, but its performance is critically dependent on the driving GCM. This study highlights the need for high-resolution observations and ensemble of climate model simulations to fully understand climate change and its impacts on small islands in the Caribbean.
\end{abstract}

Keywords: Climate change, Caribbean islands, impacts, CMIP3, RCM.

\title{
1. Introduction
}

The islands of the Caribbean share a common set of features that include small size, steep inland topography restricting the land space available for development, and a heavy socio-economic dependence on the coastline and limited resources. These features enhance sensitivity to climate variability so that extreme events such as droughts, floods and hurricanes pose a very real threat to regional development. The threat is likely to be exacerbated under climate change.

For example, tourism, which is a significant contributor to regional GDP, is at high climateinduced risk from flooding, sea-level rise, coastal erosion and storm surges mainly due to its coastal infrastructure (Pulwarty et al., 2010). In 2004 damages to guest rooms in Grenada from hurricanes was equivalent to $13 \%$ of GDP (OECS, 2004). Similarly, the agricultural sector, which contributes $10-35 \%$ of Caribbean GDP, is also sensitive to climate variations. Damage to the nutmeg and cocoa industries due to hurricane Ivan in 2004 resulted in loss equivalent to 10\% of Grenada's GDP (Mimura et al., 2007). Under future climate change, $46 \%$ of Caricom tourist resorts could be lost under a 1 $\mathrm{m}$ rise in sea-level (Moore, 2010; Simpson et al., 2010), while projected changes in temperature and rainfall will likely increase crop pests and diseases and the occurrence of extreme water stress (Nelson et al., 2009; Pulwarty et al., 2010; Simpson et al., 2010; Cashman et al., 2010). Past and future climate impacts on other key areas of Caribbean existence, for example, biodiversity and marine and coastal ecosystems (e.g., Fish et al., 2005; Donner et al., 2007; Hoegh-Guldberg et al., 2007; Chen 
et al., 2008) and on health and well being (e.g., Amarakoon et al., 2006; Chen et al., 2006; Ebi et al., 2006; Taylor et al., 2009) have also been studied and shown to be significant.

It is, then, the increasing recognition that changes in the climate of the Caribbean have serious socio-economic implications for the region that has resulted in a number of recent studies focusing on providing local governments with climate change projections for adaptation and mitigation purposes. Many of these studies use coarse-resolution general circulation models (GCMs) included in the fourth assessment report (AR4) of the Intergovernmental Panel on Climate Change (IPCC) to describe large-scale climatic changes in the region (e.g., Ángeles et al., 2007; Comarazamy and González, 2008; Biasutti et al., 2012). More recently, a handful of studies have used high-resolution regional climate models (RCMs) for studying climate change and its impact at spatial scales relevant for the islands (e.g., Castro et al., 2006; Centella et al., 2008; Campbell et al., 2010; Charlery and Nurse, 2010). In this study, we review what is now known about how the climate of the Caribbean has and will change under global warming, as can be gleaned from both available data and from existing literature. We do this for 15 island nations in the Caribbean that were studied as a part of the Caribsave (http://caribsave.org/) Climate Change Risk Atlas (CCCRA) project.

In this study, we use a subset of available model data (GCM and RCM) to provide information on the future climate of the Caribbean region. We also undertake (a) a comparative discussion of the performance of both GCMs and RCMs in simulating the 20th century (20C) climate of the Caribbean and (b) an assessment of the strengths and limitations of the climate change projections provided by both types of models. Because Caribbean station data are sparse, we rely on gridded datasets to examine the nuances of present-day Caribbean climate (e.g., key features and spatial variability). It is these nuances that also provide the basis for assessing model suitability for use in the region and against which climate change is evaluated.

The remainder of the paper is ordered as follows. Section 2 summarizes from literature what is known about historical climate trends in the Caribbean. Section 3 details the datasets, models and methodologies employed for the data analysis. Section 4 discusses key features of Caribbean climate as derived from the observed datasets. Sections 5 and 6 discuss $20 \mathrm{C}$ Caribbean climate and climate change projections based on GCM and RCM data for precipitation and surface air temperature respectively. A summary of results is presented in section 7 along with a discussion of some of their implications.

\section{Observed climatic changes in the Caribbean}

Historical temperature trends for the Caribbean have been shown to match global change (Frich et al., 2002; Peterson et al., 2002; IPCC, 2007). The intra-annual extreme range has been decreasing slightly although the trend is not significant (Peterson et al., 2002). Singh (1997) attributes the decrease in part to increased cloud cover at night that leads to back radiation and the heating of the land. Maximum temperature is increasing with the trend significant at the $1 \%$ level. Peterson et al. (2002) relate this to warmer sea surface temperatures (SSTs), though local SSTs only account for $25 \%$ of variance. Singh (1997) shows increased maximum temperatures for stations in Trinidad $\left(1-1.2{ }^{\circ} \mathrm{C}\right)$, San Juan $\left(2.3{ }^{\circ} \mathrm{C}\right)$ and Guadeloupe $\left(1.3{ }^{\circ} \mathrm{C}\right)$. The Trinidad station also shows an increase in minimum temperatures, with the trend accelerated during the 1980s (Singh, 1997). Naranjo and Centella (1998) also show an increase in mean annual temperatures for Cuba due mainly to a significant positive trend in minimum temperatures. For the region, the upward trend in 
minimum temperatures is significant at the $1 \%$ level (Peterson et al., 2002) and, as with maximum temperatures, linked to changes in SSTs, though the correlations are weaker and negative.

Precipitation also matches the global average changes (Frich et al., 2002; Peterson et al., 2002; IPCC, 2007). Precipitation in the Caribbean is dominated by variability on annual and decadal scales. It is most closely related to SSTs in the South Caribbean Sea, and somewhat to the tropical North Atlantic SSTs (Spence et al., 2004; Stephenson et al., 2007). Neelin et al. (2006) show that the Caribbean is drier by $1-12 \mathrm{~mm}$ per month or $5-30 \%$ of rainfall per 100 years with a trend that is significant at 5\% level. Singh (1997) shows a decrease in precipitation for five of the eight stations across the Caribbean, with the exceptions being the Bahamas, Venezuela and one of Trinidad's stations. The simple daily intensity index shows a slight decrease, and although the trend is not significant, it correlates well (0.41) with intense hurricanes (Peterson et al., 2002). Maximum precipitation (95th percentile and above) is increasing, but it is not significant at the $10 \%$ level, probably due to the inter-annual and decadal variability. The greatest five day rain total is increasing with a significant trend at the $10 \%$ level and also displays significant inter-annual variability. The number of consecutive dry days has decreased and the trend is significant at the 1\% level (Peterson et al., 2002). Additionally, Neelin et al. (2006), using station and satellite precipitation data, show a drying trend between June and August in the Caribbean in the last few decades.

The IPCC AR4 reported an increase in global sea level at the rate of $1.8 \pm 0.5 \mathrm{~mm} /$ year between 1961 and 1993, and at the rate of $3.1 \pm 0.7 \mathrm{~mm} /$ year from 1993 to 2003 (IPCC, 2007). Sea level rise of around 1.5 to $3 \mathrm{~mm}$ per year (1950-2000) has been observed at tidal gauging stations around the Caribbean making the regional trend similar to that for the globe (Church et al., 2004). Future sea level projections are uncertain mainly owing to difficulties in predicting the melt rates of the Greenland and Antarctic ice sheets. The IPCC AR4 indicates an increase of mean global sea level by 18 to $59 \mathrm{~cm}$ by 2100 under the A2 emissions scenario (IPCC, 2007) with recent studies suggesting an even more rapid increase. Simpson et al. (2010) discuss the likelihood of 1 or $2 \mathrm{~m}$ sea level rise in the Caribbean under either a 2.0 or $2.5^{\circ} \mathrm{C}$ global warming scenario and how it would affect costal infrastructure in the region.

Other variables are not easily available across the Caribbean for long time periods and as such their trends have yet to be seriously studied.

\section{Data, models, and methodology}

Observation datasets used in this study include gridded observational and reanalysis products (see Table I). The GCMs used in this study are a part of the third phase of the Coupled Model Intercomparison Project (CMIP3; Meehl et al., 2007) and were used in the IPCC AR4. The subset of GCMs (15) used in this study are listed in McSweeney et al. (2010; see Table II) and are described in more detail in Randall et al. (2007; see pp. 597-599). We refer to these models as CMIP3 models. All the GCM data are first regridded to a common $2.5 \times 2.5^{\circ}$ latitude-longitude grid before carrying out the analysis. We then use this multi-model ensemble to compute ensemble mean and median projections and to find the range of projections across the models. Mean climate and the climate change projections for every country are calculated by including grid boxes that lie fully or partially within the political boundaries of that country. The dynamical downscaling technique was used to downscale GCM data to $50 \mathrm{~km}$ resolution using the UK Hadley Centre regional climate 
Table I. Observational datasets used in this study.

\begin{tabular}{|c|c|c|c|}
\hline Dataset & Resolution & Details & References \\
\hline \multicolumn{4}{|l|}{ Precipitation (PRCP) } \\
\hline $\begin{array}{l}\text { Climate Research Unit } \\
(\mathrm{CRU})\end{array}$ & $0.5 \times 0.5^{\circ}$ & $\begin{array}{l}\text { Land-only gridded station } \\
\text { observations }\end{array}$ & New et al., 2002 \\
\hline $\begin{array}{l}\text { University of Delaware } \\
\text { (UDel) }\end{array}$ & $0.5 \times 0.5^{\circ}$ & $\begin{array}{l}\text { Land-only gridded station } \\
\text { observations }\end{array}$ & Matsuura and Willmott, 2007a, b \\
\hline $\begin{array}{l}\text { Global Precipitation } \\
\text { Climatology Centre } \\
(\text { GPCC })\end{array}$ & $0.5 \times 0.5^{\circ}$ & Gridded observations & $\begin{array}{l}\text { Rudolf and Schneider, 2005; } \\
\text { Rudolf } \text { et al., } 2005\end{array}$ \\
\hline $\begin{array}{l}\text { Climate Prediction Center } \\
\text { Merged Analysis of } \\
\text { Precipitation (CMAP) }\end{array}$ & $2.5 \times 2.5^{\circ}$ & Satellite & Xie and Arkin, 1997 \\
\hline $\begin{array}{l}\text { Tropical Rainfall } \\
\text { Measuring Mission } \\
\text { (TRMM) }\end{array}$ & $0.25 \times 0.25^{\circ}$ & Satellite & Huffman et al., 2007 \\
\hline
\end{tabular}

Sea surface temperature (SST)

\begin{tabular}{|c|c|c|c|}
\hline $\begin{array}{l}\text { Hadley Centre SST } \\
\text { (HadISST) }\end{array}$ & $1 \times 1^{\circ}$ & $\begin{array}{l}\text { In situ observations and } \\
\text { satellite-derived estimates }\end{array}$ & Rayner et al., 2003 \\
\hline
\end{tabular}

Sea level pressure (SLP), wind speed (WSP)

\begin{tabular}{lll}
\hline NCEP & $2.5 \times 2.5^{\circ}$ & Reanalysis \\
\hline
\end{tabular}

modelling system called PRECIS (Providing Regional Climates for Impacts Studies). A detailed description of the RCM domain and the methodology is discussed in Campbell et al. (2010) and Centella et al. (2008). The PRECIS RCM simulations are driven by the HadAM3P and ECHAM4 GCMs (see Jones et al., 2004).

Climate change projections are calculated for the 2080s (mean of 2080-2089) for the SRES A2 scenario relative to the mean climate of 1970-1989. These two time slices are chosen because they provide maximum overlap between all the GCM and RCM data included in this study. The discussion is also limited to one scenario because of data availability at the time of writing. The SRES A2 scenario, being the high emissions scenario (IPCC, 2000), gives projections that lie towards the high-end of the range of projections based on all the available emissions scenarios. Even though all the scenarios described in IPCC (2000) are equally plausible, it has been shown that the spatial pattern of response for key variables such as temperature and precipitation is very similar across all the scenarios in this region and differs significantly only in its magnitude (Mitchell, 2003). Therefore the results presented here can be scaled to determine approximate projections for other scenarios. Table II describes the nature of information generated in this study with the help of precipitation information for Anguilla, as an example. Similar information on precipitation and temperature for all 15 island states included in this study is tabulated in Tables $\underline{\mathrm{S} 1}$ and $\underline{\mathrm{S} 2}$ of the supplementary material. 
Table II. Island-specific precipitation data. Observed and simulated means for the period 1970-1989 for all season and climate change projections based on the CMIP3 ensemble and RCM simulations for the SRES A2 scenario. This table shows results for Anguilla. Similar information is summarized in Table $\underline{\mathrm{S} 1}$ of supplementary material for the following countries: Anguilla, Antigua and Barbuda, the Bahamas, Barbados, Cuba, Dominica, Dominican Republic, Grenada, Haiti, Jamaica, St Kitts and Nevis, St Lucia, St Vincent and the Grenadines, Trinidad and Tobago, Turks and Caicos Islands.

\begin{tabular}{|c|c|c|c|c|c|c|}
\hline \multirow[t]{2}{*}{ Season } & \multirow[t]{2}{*}{ Dataset } & \multirow{2}{*}{$\begin{array}{l}\text { Mean } \\
\text { climate } \\
(\mathrm{mm} / \\
\text { month) }\end{array}$} & \multicolumn{4}{|c|}{ Projections (SRES A2 scenario) } \\
\hline & & & $\begin{array}{c}\text { Mean } \\
(\mathrm{mm} / \text { month, \%) }\end{array}$ & $\begin{array}{c}\text { Min } \\
(\mathrm{mm} / \mathrm{month}, \%)\end{array}$ & $\begin{array}{c}\text { Median } \\
(\mathrm{mm} / \text { month, \%) }\end{array}$ & $\begin{array}{c}\text { Max } \\
(\mathrm{mm} / \mathrm{month}, \%)\end{array}$ \\
\hline Annual & $\begin{array}{l}\text { CMIP3 } \\
\text { RCM-H } \\
\text { RCM-E } \\
\text { OBS }\end{array}$ & $\begin{array}{r}57.3 \\
126.8 \\
62.7 \\
110.7\end{array}$ & $\begin{array}{r}-9.8(-18.4) \\
-31.2(-24.6) \\
-3.6(-5.7)\end{array}$ & $-33.9 \quad(-55.3)$ & $-7.0(-22.8)$ & $7.4(16.5)$ \\
\hline Dry & $\begin{array}{l}\text { CMIP3 } \\
\text { RCM-H } \\
\text { RCM-E } \\
\text { OBS }\end{array}$ & $\begin{array}{l}38.9 \\
86.5 \\
59.3 \\
76.6\end{array}$ & $\begin{array}{rc}-1.4 & (-5.2) \\
-0.2 & (-0.2) \\
0 & (0)\end{array}$ & $-13.7 \quad(-41.0)$ & $-0.2 \quad(-1.2)$ & $6.4(21.5)$ \\
\hline Wet & $\begin{array}{l}\text { CMIP3 } \\
\text { RCM-H } \\
\text { RCM-E } \\
\text { OBS }\end{array}$ & $\begin{array}{r}70.4 \\
155.5 \\
65.0 \\
135.1\end{array}$ & $\begin{array}{r}-15.8(-23.2) \\
-53.3(-34.3) \\
-6.2(-9.5)\end{array}$ & $-48.3(-68.2)$ & $-10.7(-23.2)$ & $10.5(18.5)$ \\
\hline MJJ & $\begin{array}{l}\text { CMIP3 } \\
\text { RCM-H } \\
\text { RCM-E } \\
\text { OBS }\end{array}$ & $\begin{array}{r}50.7 \\
139.2 \\
54.1 \\
109.9\end{array}$ & $\begin{array}{rr}-17.1 & (-32.2) \\
-50.5 & (-36.3) \\
3.1 \quad(5.7)\end{array}$ & $-45.7(-70.6)$ & $-14.2(-24.0)$ & $-1.7(-5.0)$ \\
\hline ASON & $\begin{array}{l}\text { CMIP3 } \\
\text { RCM-H } \\
\text { RCM-E } \\
\text { OBS }\end{array}$ & $\begin{array}{r}85.2 \\
167.8 \\
72.9 \\
154.0\end{array}$ & $\begin{array}{l}-14.9(-20.0) \\
-55.4(-33.0) \\
-12.8(-17.6)\end{array}$ & $-54.3(-69.3)$ & $-10.3(-13.1)$ & $22.7(29.8)$ \\
\hline
\end{tabular}

\section{20th century climate of the Caribbean}

\subsection{Observed precipitation}

From the point of view of climate change and its impacts, change in precipitation remains one of the most important parameters for the Caribbean. The islands in the Caribbean experience two distinct seasons in general: a dry season from November through April and a wet season from May through October (Granger, 1985; Taylor and Alfaro, 2006). Precipitation magnitude varies considerably from the Bahamas to the southernmost islands of the Lesser Antilles and mountainous topography and its orientation with respect to the direction of trade winds further yield large spatial variations in precipitation on many islands (Granger, 1985; Sobel et al., 2011). A prominent feature of the seasonal cycle of precipitation is the mid summer drought (MSD) (Magaña et al., 1999), which is not a real drought but a period during the wet season months when precipitation is relatively lower resulting in a bimodal cycle of precipitation. The timing and duration of the MSD vary across the Caribbean, e.g., the MSD appears in early June in parts of the eastern Caribbean and 
in late July around Cuba and the Bahamas and is non-existent in some eastern islands (Magaña et al., 1999; Gamble and Curtis, 2008). Capturing the timing, duration and existence of the MSD in the Caribbean are important measures for both observed and simulated datasets.

Observed (Climate Research Unit, CRU; University of Delaware, UDel; Global Precipitation Climatology Centre, GPCC) zonal mean precipitation for two latitude bands-one covering most of the Greater Antilles and the Bahamas in the western Caribbean and the other over the Lesser Antilles in the eastern Caribbean (Fig. 1) - for the period 1979-2000 is shown in Figure 2. The seasonal cycle of precipitation in the western Caribbean is predominantly bimodal in nature (Fig. 2a) with first maximum in precipitation in May or June and the second maximum between August and November. Jamaica, Haiti and Dominican Republic show precipitation peaks in May and October with a relative decrease in precipitation during the intermediate months. In the Bahamas and Cuba, precipitation peaks around June and in September with a shorter MSD period relative to the islands to their south. The double peak in precipitation can be seen at all latitudes in the western Caribbean with the second peak generally greater than the first. The seasonal cycle of precipitation over the islands in the eastern Caribbean (Fig. 2b) similarly shows a bimodal cycle for most latitudes north of about $15^{\circ} \mathrm{N}$ with the late wet season peak being greater than the first maximum. For islands south of $15^{\circ} \mathrm{N}$, however, there is only one peak which occurs in the late wet season (Fig. 2b) and which is in part related to the inter-tropical convergence zone (ITCZ) reaching its northernmost position in those months. Since the CRU, UDel and GPCC datasets are based on the station network in the region, these maps represent precipitation over land.

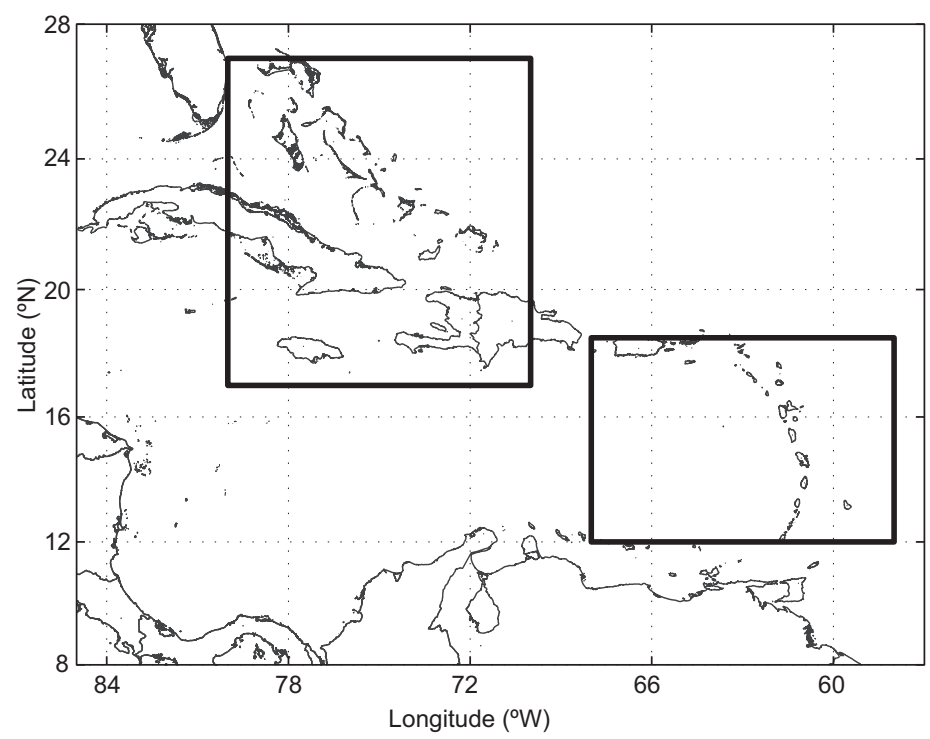

Fig. 1. Two regions of the Caribbean-western $\left(70-80^{\circ} \mathrm{W}\right)$ and eastern $\left(58-68^{\circ} \mathrm{W}\right)$ - for which zonal means are calculated.

Although satellite observations have limited temporal coverage they provide better spatial coverage for this region where station data is sparse. CPC Merged Analysis of Precipitation (CMAP) data are used for the period 1979-2000 and Tropical Rainfall Measuring Mission (TRMM) data for 1998-2007, in addition to the CRU and UDel data, to assess differences between the observation 



Fig. 2. Zonal maps of observed precipitation and SSTs for the western (left panels) and eastern (right panels) Caribbean regions shown in Figure 1. Zonal maps of precipitation based on station observations (CRU, UDel, GPCC) are shown in panels (a) and (b); CMAP in (c) and (d); and TRMM in (e) and (f). Stars in (a) and (b) mark the maximum precipitation at a given latitude. Observed SSTs (HadISST) are shown in panels (g) and (h). White dotted lines mark the $26.5^{\circ} \mathrm{C}$ threshold for convection. Rough positions of the islands are marked on the plots. 
datasets and for comparison with simulated precipitation (section 5). All the observational products show similar variations in zonal precipitation in the north-western Caribbean (Fig. 2a, c, e). All show a bimodal precipitation cycle with a longer MSD period around the Greater Antilles (Cuba, Jamaica, Hispaniola) region than that in the northern Caribbean (i.e., the Bahamas). In the eastern Caribbean, however, the second maximum in precipitation in CMAP occurs in September (Fig. 2d) instead of October-November indicated by station observations (Fig. 2b). In the TRMM product the second precipitation peak occurs around October-November in the eastern Caribbean (Fig. 2f), but it does not agree well with the magnitude of observed precipitation seen in Figure $2 \mathrm{~b}$.

Figure 2c-f also shows that the magnitude of zonal averaged precipitation for the satellite products is lower than that for the station data since the average involves contribution from the oceans. That is, the difference likely arises from variations induced by land-surface heating and the topography. This is more so evident in the eastern Caribbean region (Fig. 2d, f), which generally has very little landmass and therefore the zonal precipitation is likely dominated by precipitation over the ocean leading to disagreements between the satellite and station observation products. Jury (2009) noted several such biases in all observational products in the Caribbean, making their use in climate model evaluation challenging.

Notwithstanding, the islands of the Greater Antilles and the fairly large islands in the Lesser Antilles such as Dominica and Martinique show regional maxima in precipitation during the wet season months (Fig. 2c, e). Many islands in the Lesser Antilles from Guadeloupe to St. Lucia also receive considerably more precipitation than the surrounding waters in the satellite products (Fig. 2d, f). In addition to precipitation that results from mid-latitude air intrusions in the dry season (Schultz et al., 1998), mountainous topography gives rise to orographic precipitation during the dry season months along the windward slopes of the islands. As a result, higher precipitation totals along the windward slopes and large spatial variations in precipitation from windward to leeward slopes are observed on these islands (Reed, 1926; Smith et al., 2009). Dominica, in particular, shows over 2-3 mm/day precipitation throughout the year with a maximum of 10-12 mm/day in November (Fig. 2b). There is consistency with the results of Biasutti et al. (2012) who use TRMM high-resolution data to show that precipitation over the Caribbean islands is more frequent than over the adjacent ocean during the wet season months due to land-sea thermal contrast. Sobel et al. (2011) also demonstrate that there is a significant increase in average island precipitation (relative to the ocean surrounding it) for large islands with mountainous topography. The authors, however, suggest that small islands receive less precipitation than the surrounding ocean (Sobel et al., 2011).

\subsection{Sea surface temperatures}

One of the primary controls of seasonal precipitation in the Caribbean is SST. The tropical North Atlantic, the Caribbean Sea and the Gulf of Mexico are important sources of heat and moisture to the Caribbean. SST variability in the region affects the climate of the Caribbean, particularly in the wet season months (May-November) (Taylor et al., 2002; Wang et al., 2008) when an increase to values over $26.5^{\circ} \mathrm{C}$ creates conducive conditions for organized convection and widespread precipitation (Graham and Barnett, 1987).

The observed SSTs (Hadley Centre SST, HadISST) for the period 1970-1989 show a single peak in the seasonal cycle of SSTs around September-October in the eastern (Fig. 2g) and western 
(Fig. 2h) Caribbean. The SST threshold of $26.5^{\circ} \mathrm{C}$ for convection (marked by the dashed white line) is crossed around March-April in the central Caribbean and not until May-June around the Bahamas (Fig. 2g). The timing is consistent with variations in the onset of the wet season and the first maximum in precipitation, which occur earlier in the western Caribbean and later in the northwestern Caribbean. In the eastern Caribbean, for waters surrounding the Lesser Antilles, the $26.5^{\circ} \mathrm{C}$ threshold is crossed around April and SSTs are greater than $28.5^{\circ} \mathrm{C}$ from August through November (Fig. 2h). This strong link between precipitation and SST is manifested, in part, through the influence of SST variability on the North Atlantic high-pressure system, which is discussed below.

\subsection{The North Atlantic subtropical high and the Caribbean low-level jet}

Though we do not illustrate it with diagrams, it is important to note that a second major control of seasonal precipitation in the Caribbean is the pressure gradient determined by the North Atlantic subtropical high (NASH) and the equatorial low-pressure band. Whereas SSTs control organized convection, the sea level pressure (SLP) variability controls the magnitude and direction of the trade winds in the Caribbean.

Wang (2007) and Wang and Lee (2007) demonstrate that the seasonal movement and changes in the intensity of the NASH are intimately linked to changes in precipitation through its relation to SSTs and influence on winds. Lowest SLP generally helps to define the wet season months. During the months of July and August, SLP increases due to a brief intrusion of the NASH, particularly in the western Caribbean. Gamble and Curtis (2008) note that this is a contributory factor to the MSD. Precipitation peaks again when the SSTs reach their maximum values and SLP its minimum value of the year for a given latitude. Note, then, that the seasonal cycle of SSTs in the Caribbean Sea has only one peak during late summer (see again Fig. $2 g, h$ ) unlike the precipitation seasonal cycle, but the seasonal cycle of local SLP has two peaks. SLP peaks in boreal winter (the dry season) and again during mid-summer and is also associated with peak intensities in easterly trade winds in the Caribbean Sea (Wang, 2007; Amador, 2008; Muñoz et al., 2008; Whyte et al., 2008). This latter feature is commonly known as the Caribbean low-level jet (CLLJ), which is essentially the intensified easterly trade winds along the southern flank of the NASH resulting from a large meridional pressure gradient in the region. We further note that the CLLJ also has a bimodal seasonal cycle with maxima in July and February associated with the movement of the NASH and heating over the tropical South America (Wang and Lee, 2007; Cook and Vizy, 2010). A number of studies note a strong negative correlation between Caribbean precipitation and the strength of the CLLJ (Muñoz et al., 2008; Whyte et al., 2008; Cook and Vizy, 2010; Taylor et al., 2012), particularly during the wet season months. An increase in the CLLJ intensity in July is associated with a decrease in precipitation, whereas a minimum in CLLJ strength in OctoberNovember coincides with peak precipitation in the region.

\section{Simulated Caribbean precipitation}

\subsection{Climate model performance}

Though GCMs generally face difficulty capturing the variety of climate regimes present at the islandlevel, they can still be tested for their ability to simulate the synoptic-scale features that shape the climate of the region. The degree to which the presence of an island can influence regional circulation 
depends on the island's size and topographic features (Sobel et al., 2011). This effect is small for the small islands in the Caribbean (Chan et al., 2011; Sobel et al., 2011). Therefore, it is reasonable to expect that the CMIP3 models should still capture the large-scale circulation features of the Caribbean. Regional climate models operational at 25 to $50 \mathrm{~km}$ horizontal resolution are more appropriate for studies of climate change in the Caribbean islands, but their performance also needs to be thoroughly validated against observations.

Simulated 20C precipitation in the CMIP3 models (Fig. 3a, b) can be compared with CMAP precipitation for the period of overlap 1979-1989. Comparisons between Figures 3a, 2c and 3b, $2 \mathrm{~d}$ indicate underestimation of the CMIP3 ensemble mean precipitation relative to CMAP during the wet season in both the western as well as eastern Caribbean. Since, as noted previously, islands receive more precipitation than the surrounding waters due to the effects of land-sea thermal contrasts and topography, underestimation of precipitation by the GCMs that do not resolve these islands is expected. But even at larger spatial scales, the CMIP3 GCMs have been shown to systematically underestimate precipitation in the region (Dai, 2006). Many CMIP3 models fail to capture the first peak in precipitation seen in the region and the ones that do capture it severely underestimate precipitation during the early wet season months (not shown). In the western Caribbean, the ensemble mean precipitation shows a dry bias in Jamaica and Hispaniola (Fig. 4a), particularly in the wet season. Over Cuba and the Bahamas, CMIP3 ensemble mean shows a dry bias in the early wet season and a wet bias in the late wet season. In the eastern Caribbean, precipitation is underestimated over the Lesser Antilles from April through November (Fig. 4b). It is important to note, however, that CMAP precipitation does not agree well with other observations in this latter region (see previous section).

Sensitivity of model convection schemes to SSTs and SST underestimation in the Caribbean region (Wang and Lee, 2007) are thought to be partially responsible for the dry bias in wet season precipitation (Dai, 2006). Figure 3g, h show that although the seasonal cycle of SSTs is fairly well captured in the CMIP3 ensemble mean, the simulated SSTs are lower by about $0.5-1.5^{\circ} \mathrm{C}$ than the observed SSTs throughout most of the year (Fig. $4 \mathrm{~g}, \mathrm{~h}$ ). This is consistent with Rauscher et al. (2008), who show that the CMIP3 ensemble underestimates SSTs by about $1{ }^{\circ} \mathrm{C}$ in JJA in the tropical North Atlantic, the Caribbean Sea and the Gulf of Mexico. Rauscher et al. (2008) also demonstrate that higher resolution GCMs have smaller precipitation bias making horizontal resolution of the models an important factor. The underestimation of precipitation in the CMIP3 ensemble is also linked to an overestimation of SLPs in the region (Fig. 5). Early wet season minimum in SLP in the western Caribbean, as shown by NCEP reanalysis data, is not well simulated in the CMIP3 ensemble mean. Notwithstanding, the semi-annual features in the local SLP and CLLJ in the Caribbean are reproduced by the CMIP3 model ensemble mean (Fig. 5) so the late wet season precipitation peak coincides with the yearly maximum in SSTs and the yearly minimum in SLPs and wind speeds. Martin and Schumacher (2011) show that all the CMIP3 models successfully capture and maintain the observed features of the CLLJ, but some have difficulty in simulating its semi-annual seasonal cycle.

PRECIS RCM simulations driven by the HadAM3P (RCM-H hereafter) and ECHAM4 (RCM-E hereafter) GCMs show varied performance when compared with observations. RCM-H mostly overestimates precipitation (Fig. 4c, d) relative to CMAP in both regions except for latitudes between Cuba and Hispaniola in the wet season, whereas RCM-E underestimates precipitation in the wet season in both regions (Fig. 4e, f). In general, all these simulations show a tendency towards a dry 

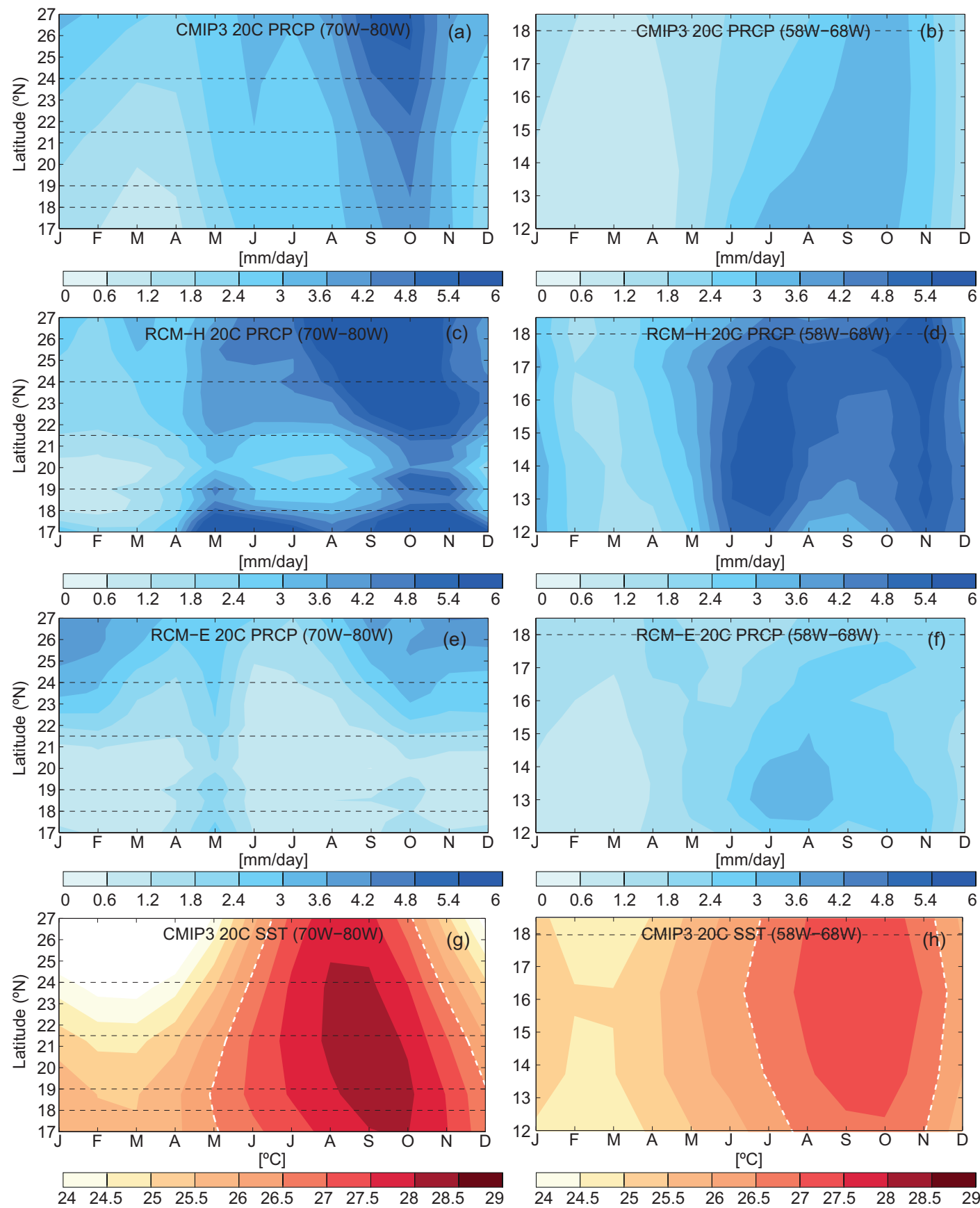

Fig. 3. Simulated zonal mean precipitation for the 20th century (1970-1989) for the western (left panels) and eastern (right panels) Caribbean regions shown in Fig. 1. (a, b) CMIP3 ensemble mean PRCP; (c, d) RCM-H PRCP; (e, f) RCM-E PRCP; (g, h) CMIP3 ensemble mean SSTs.

bias in the early and late wet seasons. The spatial pattern of precipitation biases in the HadAM3P GCM and RCM (not shown) suggest that uncertainties in the driving model may be, to some extent, responsible for precipitation biases seen in the RCM. Nonetheless, previous studies have 

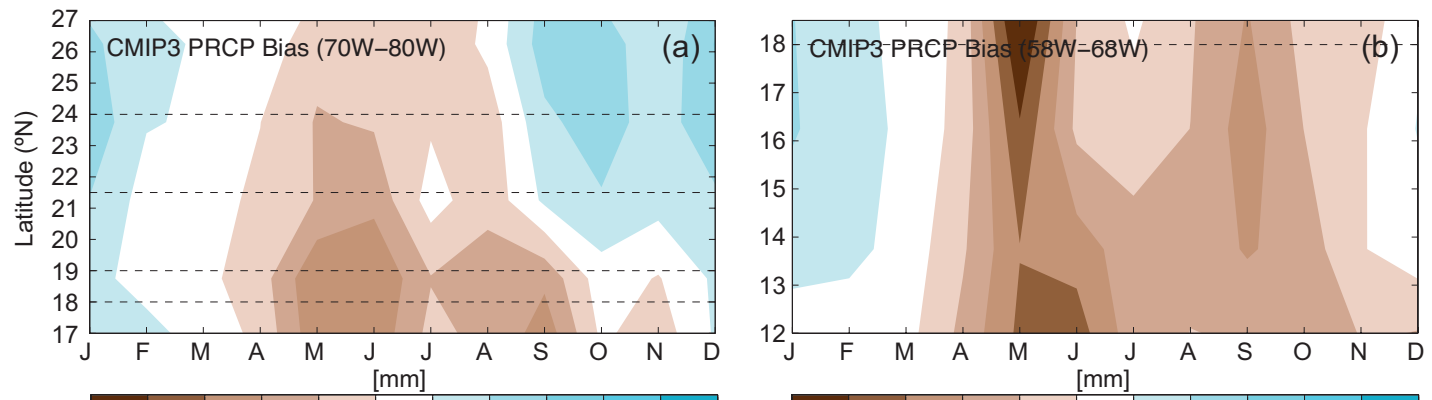

$\begin{array}{llllllll}-2.75-2.25-1.75-1.25 & -0.75-0.25 & 0.25 & 0.75 & 1.25 & 1.75 & 2.25 & 2.75\end{array}$
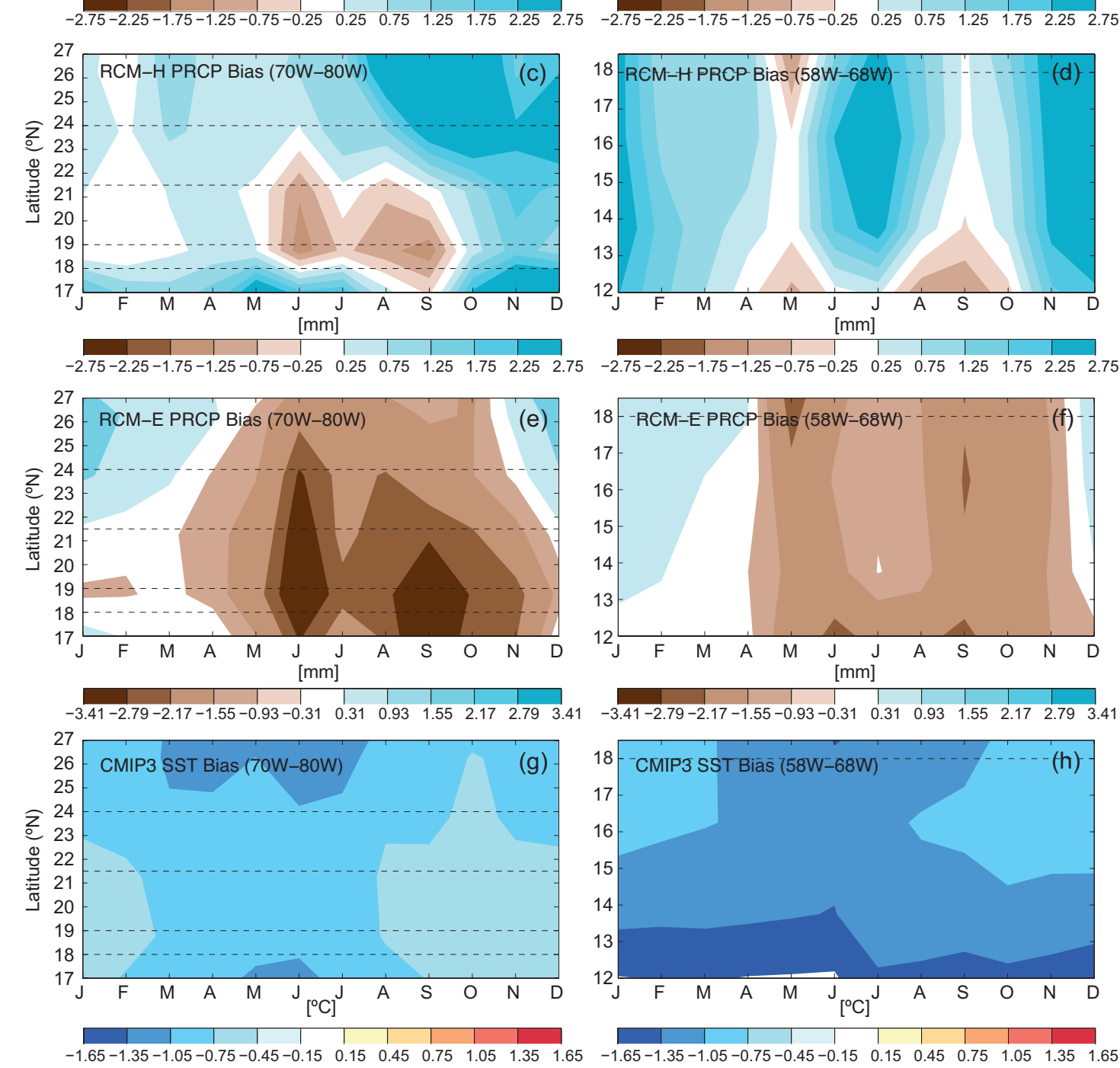

Fig. 4. Precipitation biases in simulated precipitation relative to CMAP data and in SSTs relative to HadISST data for the western (left panels) and eastern (right panels) Caribbean regions shown in Fig. 1. (a, b) PRCP: CMIP3-CMAP; (c, d) PRCP: RCM-H-CMAP; (e, f) PRCP: RCM-E-CMAP; (g, h) SST: CMIP3-HadISST. 
(a)

PRCP

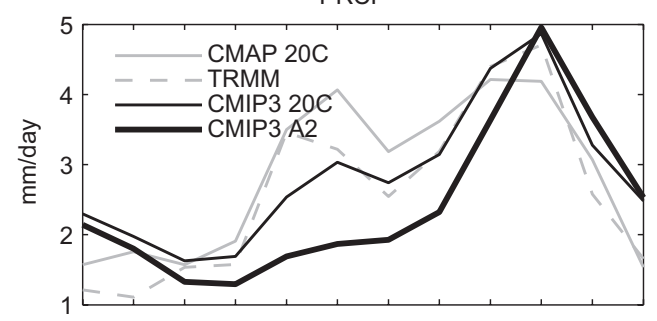

SLP
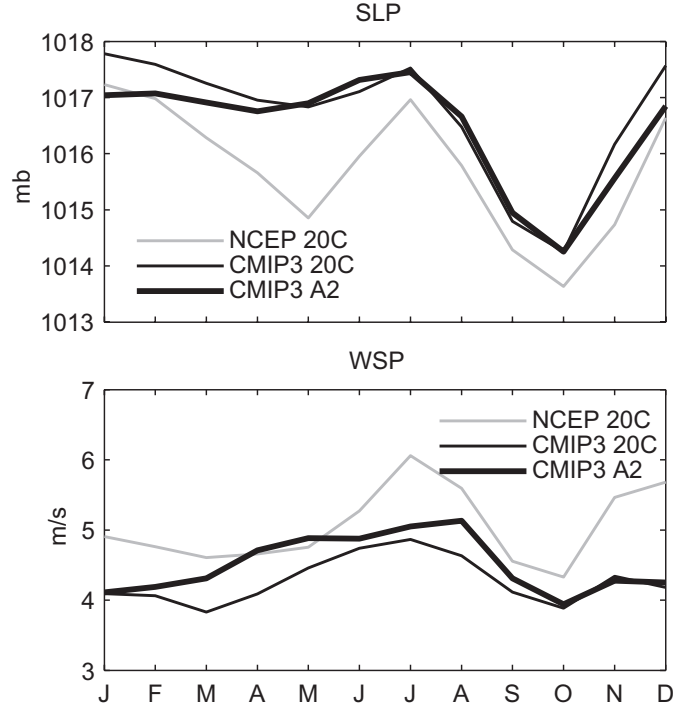

(b)
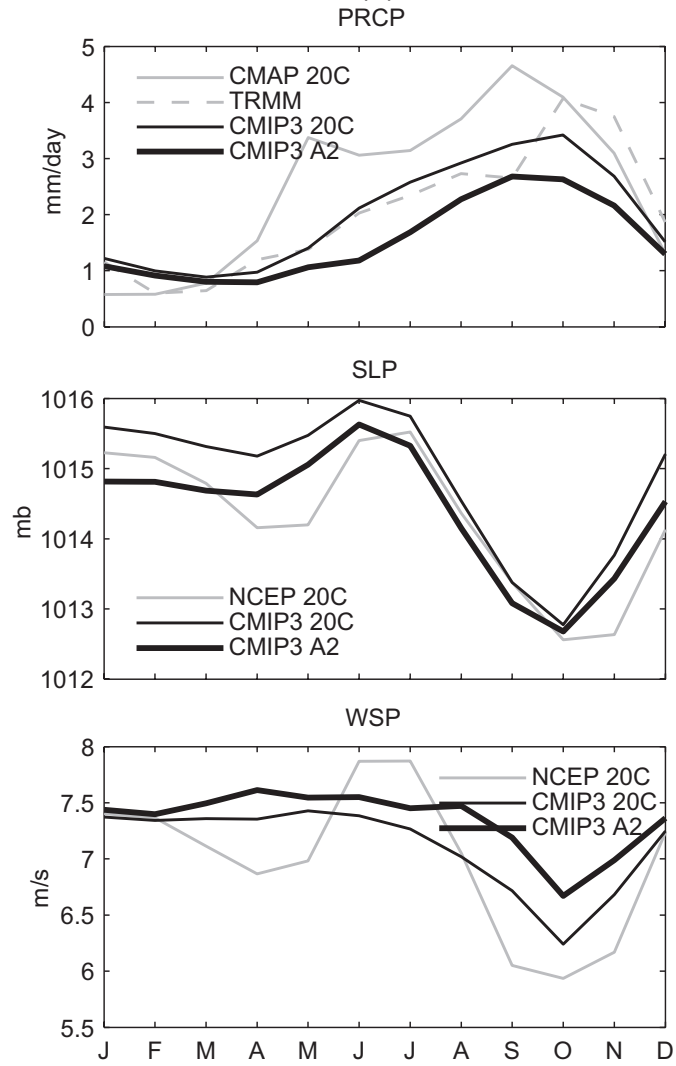

Fig. 5. Comparisons between observed and simulated season cycles of precipitation, SLP and wind speeds averaged over the boxes shown in Fig. 1. Left panels are for the western Caribbean and right panels for the eastern Caribbean.

shown the importance of added value of PRECIS RCM in the Caribbean (Campbell et al., 2010) and in Central America (Karmalkar et al., 2008, 2011). Overestimation of precipitation in the late season at higher latitudes in the western Caribbean and underestimation of precipitation in the wet season in Jamaica and Hispaniola have been noted in Campbell et al. (2010) and can be linked to similar biases in the driving model (HadAM3P). The RCM-H captures the bimodal nature of the precipitation cycle in Cuba, Hispaniola and Jamaica, but not in the Bahamas (Fig. 3c). In the eastern Caribbean, where observations show a single precipitation peak in November, RCM-H shows two peaks, one around June-July and the second one in November (Fig. 3d). Overall, the underestimation of precipitation in the wet season and overestimation in the dry season demonstrates the models' difficulty in capturing the seasonal precipitation variability in the region.

\subsection{Precipitation projections}

Most CMIP3 models (and therefore the ensemble median projections) indicate a decrease in precipitation in the Caribbean under the SRES A2 scenario (Fig. 6, Table S1). Figure 6 focuses on the wet season when the region receives most of its precipitation. The proportional decrease in precipitation is higher during the early (MJJ) than the late (ASO) wet season (Fig. 6a, b). 
In MJJ, the CMIP3 ensemble median projections for the 2080s relative to 1970-1989 mean indicate drying by $30-40 \%$ in the western Caribbean and by $20-30 \%$ in the eastern Caribbean (Fig. 6a). In ASO, the proportional drying is $10-25 \%$ in the western Caribbean and $20 \%$ in the eastern Caribbean (Fig. 6b). Overall, the region around Haiti and Dominican Republic shows

(a) [2080-89(SRES A2) - 1970-89], PRCP (\%), MJJ



(b)

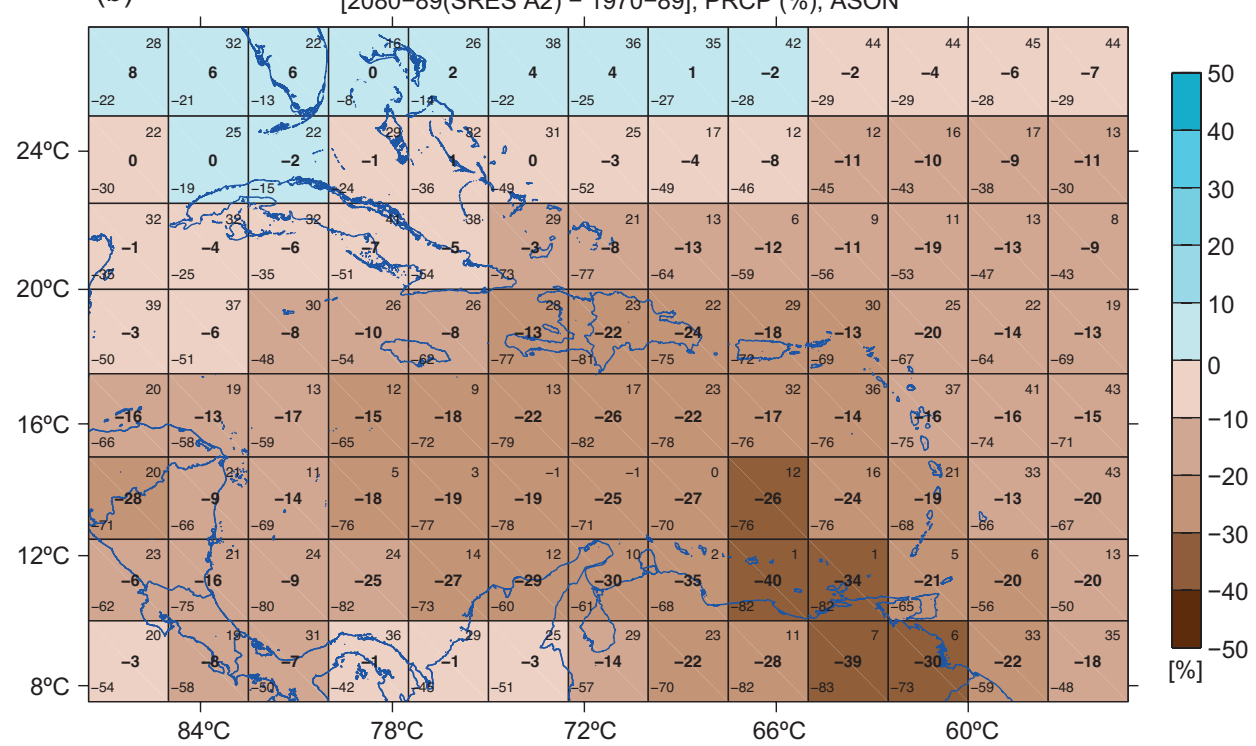

Fig. 6. Projected change in precipitation (\%) by the 2080s under the SRES A2 scenario based on the CMIP3 multi-model ensemble for the following seasons (a) MJJ (early wet season), (b) ASON (late wet season). Projected change by the 2080s is relative to the mean climate of 1970-1989. For every grid box, the color indicates ensemble mean projection, the value at the center indicates ensemble median projection and values at the bottom-left and topright corners indicate ensemble minimum and maximum projections respectively. 
largest decrease during both MJJ and ASO. In contrast there are relatively small changes in the northern Bahamas. Although there is a general agreement between models on the sign of change, the model projections across the CMIP3 ensemble range from -80 to $+5 \%$.

Large projected decreases in precipitation in the early wet season smooth out the bimodality in the western Caribbean in the ensemble mean projections (Fig. 5, top left panel), but the shape of the seasonal cycle remains unchanged in the eastern Caribbean (Fig. 5, top right panel). The dry season experiences very little proportional decrease in precipitation in the Caribbean under the SRES A2 scenario, while there is a small increase in precipitation in November in the northwest Caribbean in the Bahamas.

Both RCM simulations project a decrease in precipitation in the early and late dry season (Fig. 7c, f; also see Table $\underline{\mathrm{S} 1}$ ), but the magnitude of change is very different with RCM-H projecting much higher decrease than the RCM-E. Projected changes in precipitation throughout the year are also very different in the two RCM simulations. RCM-H projects year-round decrease in precipitation in Jamaica and Hispaniola whereas the RCM-E indicates small increases between November and January in this region (Fig. 7c, e). The Bahamas islands, in both RCM simulations, are projected to experience wetter conditions in the dry season. In the eastern Caribbean the agreement between the two RCM projections is poor (Fig. 7d, f).

Local SSTs in both the western and eastern Caribbean are projected by the CMIP3 ensemble to increase by about $1-3.5^{\circ} \mathrm{C}$ by the 2080 s relative to $1970-89$ mean under the SRES A2 scenario (Fig. $7 \mathrm{~g}, \mathrm{~h}$ ). In general, the SST warming is higher in the months from March through July in the western Caribbean with largest increase in the northwestern Caribbean around the Bahamas. Though warmer SSTs may seem incongruous with the strong projected drying during this period, Taylor et al. $(2011,2012)$ argue that it is SST gradients across the tropical oceans that are important. SSTs in the tropical North Atlantic and the Caribbean Sea are projected to increase less compared to other tropical regions (Vecchi and Soden, 2007) due to the influence of northeast trades (Leloup and Clement, 2009). Therefore, the waters surrounding the Lesser Antilles warm less compared to the Gulf of Mexico and waters surrounding the Bahamas (Fig. 7h). These variations have been shown to play a role in wet season drying projected by the models (Rauscher et al., 2011). We also note that the projected decrease in early summer (May-August) precipitation has been shown to be related to low-level divergence in the Caribbean associated with an early intrusion of NASH in the region (Rauscher et al., 2008) and strengthening of low-level easterlies (Vecchi and Soden, 2007; Cook and Vizy, 2010, Taylor et al., 2012). A projected precipitation decrease in the early wet season could also be associated with the southward displacement of the ITCZ (Rauscher et al., 2008).

\section{Simulated surface air temperature (SAT)}

\subsection{Climate model performance}

The Caribbean, being in the tropical belt, experiences very little variation in temperatures during the course of a year. Daily temperature range is slightly higher than the annual range, which varies between 2 and $5.5^{\circ} \mathrm{C}$ from southern Caribbean to Cuba (Granger, 1985). A comparison of simulated SAT with observations shows that the CMIP3 models have a cold bias for all the small islands that are not resolved in the coarse-resolution GCMs (Table $\underline{\mathrm{S} 2}$ ). This is so because the CMIP3 models represent temperatures over the ocean that are naturally lower than those shown by the land-based station observations (CRU, UDel). For islands that are partially resolved in the CMIP3 models, 

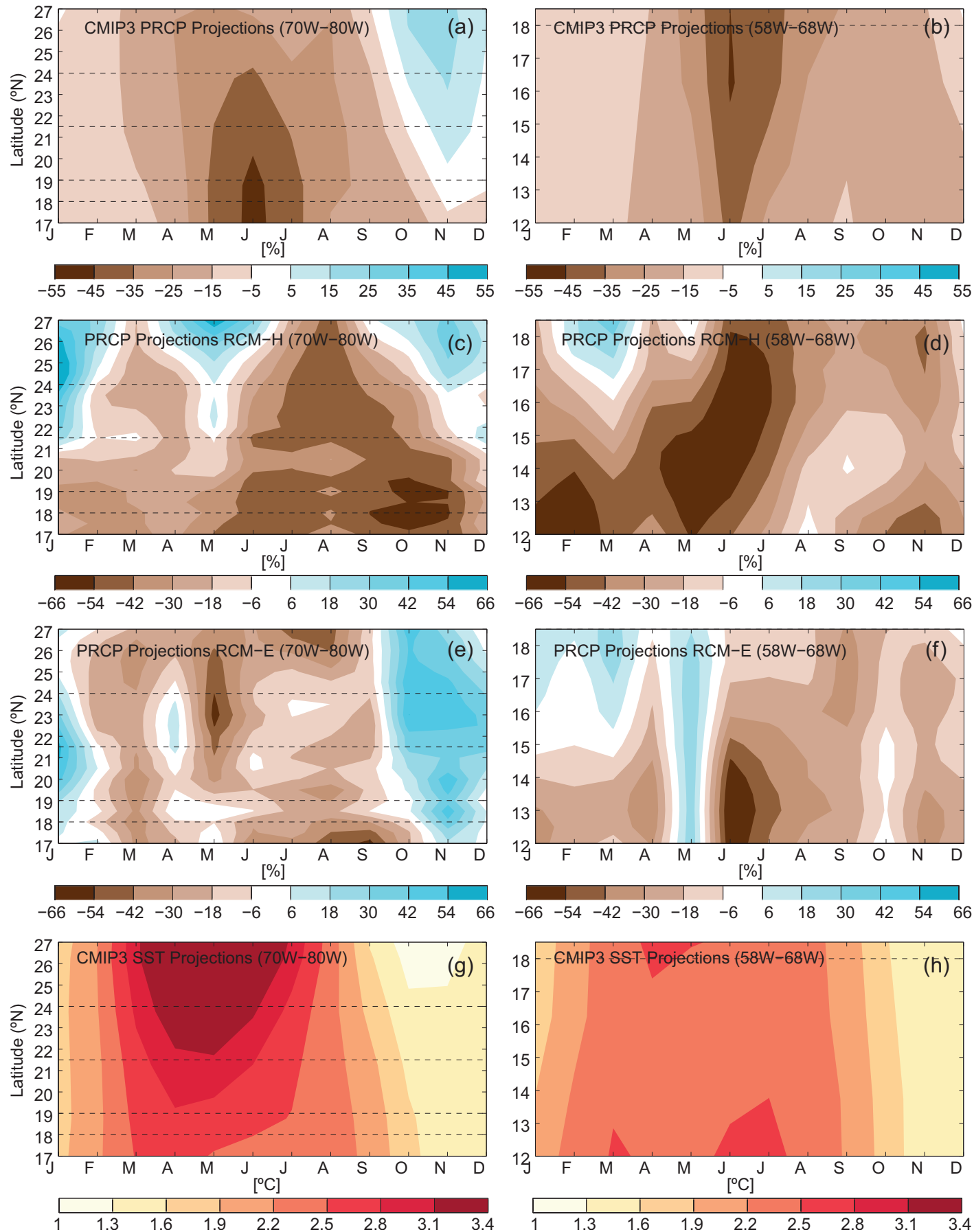

Fig. 7. Projected zonal mean precipitation and SSTs for the 2080s relative to 1970-1980 mean under the SRES A2 scenario over the western (left panels) and eastern (right panels) Caribbean regions shown in Fig. 1. (a, b) CMIP3 ensemble mean PRCP; (c, d) RCM-H PRCP; (e, f) RCM-E PRCP; and (g, h) CMIP3 ensemble mean SSTs. 
such as Jamaica, Hispaniola and Cuba, the ensemble mean SATs show a warm bias (Table $\underline{\mathrm{S} 2}$ ). For the small islands, the RCM simulations show a warm bias with RCM-E consistently showing a larger bias in all seasons compared to RCM-H (Table $\underline{\mathrm{S} 2}$ ).

All the islands in the Caribbean show statistically significant increasing SAT trends from 19702006 except for some parts of Cuba, where the SAT trends are slightly negative (not shown). Trends in observed mean annual SAT for the period 1970-89 are positive but not statistically significant for all islands. CMIP3 ensemble mean, however, shows statistically increasing SAT trends for this period, which are generally smaller than the observed trends (Table $\underline{\mathrm{S} 2}$ ). RCM simulations also show increasing SAT trends, but they are not always statistically significant.

\subsection{SAT projections}

Spatial maps of projected changes in SAT based on the CMIP3 multi-model ensemble for the SRES A2 scenario show higher warming in the northwestern Caribbean and relatively lower warming in the southeastern Caribbean (Fig. 8a). Note that Figure 8a shows a range of projections spanned by the CMIP ensemble, in addition to ensemble mean and median projections. Mean annual warming ranges from $2.4^{\circ} \mathrm{C}$ in the eastern Caribbean to about $2.9^{\circ} \mathrm{C}$ over Cuba in the western Caribbean. Although the magnitudes are different, this spatial pattern of warming is consistent throughout the year. We note again that the small islands of the Lesser Antilles are not represented in the CMIP3 models, and therefore projections discussed here simply describe warming over water. The multimodel spread in SAT projections is about $1-1.5^{\circ} \mathrm{C}$ in the region and is, in general, higher for land grid-boxes than those over water.

It is expected that the RCM simulations will indicate higher warming over land than water given the better representation of the landmass at $50 \mathrm{~km}$ model resolution. The available RCM simulations show a similar spatial pattern of warming as the CMIP3 multi-model ensemble but with higher warming over the bigger islands (Cuba, Hispaniola, and Jamaica) (Fig. 8b, c). Between the RCMs, the simulation driven by ECHAM4 projects higher increases in mean annual and seasonal SAT than that driven by HadAM3P. Furthermore, mean annual warming indicated by the RCM-E projections is higher than any models in the CMIP3 ensemble for all the islands in the Caribbean included in this study (Table $\underline{\mathrm{S} 2}$ ). RCM-H projections are similarly higher compared to median projections of the CMIP3 ensemble for all islands except Trinidad and Tobago, Turks and Caicos and Grenada. The RCM projections also show that smaller islands in the Lesser Antilles that are resolved in RCM simulations (Dominica, Martinique, St. Lucia and Barbados) show slightly more warming than that over the surrounding waters.

Finally, early wet season warming in the CMIP3 ensemble seems to be closely related to projected drying during these months (see Table $\underline{\mathrm{S} 2}$ ) with higher warming and more drying for big islands such as Cuba and Jamaica. The relationship is not so evident for other seasons. ECHAM-driven PRECIS simulation also projects higher warming and less drying under the SRES A2 scenario compared to CMIP3 ensemble and RCM-H projections.

\section{Summary and discussion}

This article evaluates the ability of GCMs and an RCM to both capture mean climate and the season cycles of key climate variables in the Caribbean and then summarizes climate change information 
(a)

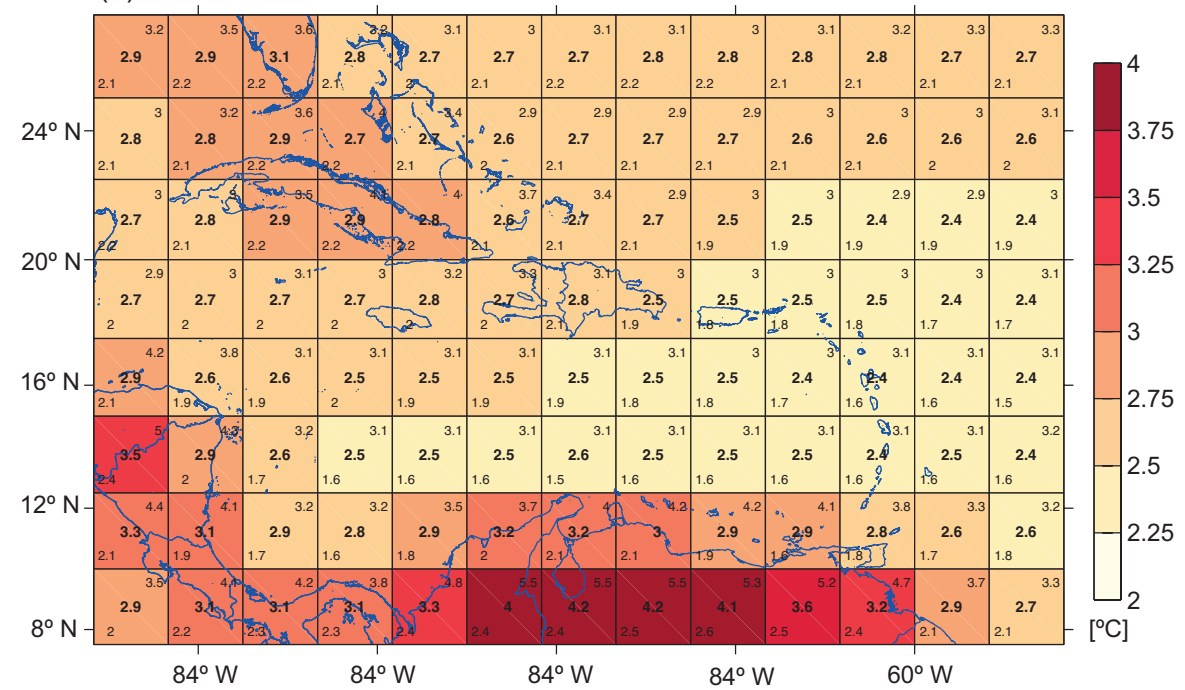

[2080-89(SRES A2) - 1970-89], RCM-H SAT $\left({ }^{\circ} \mathrm{C}\right)$, ANN

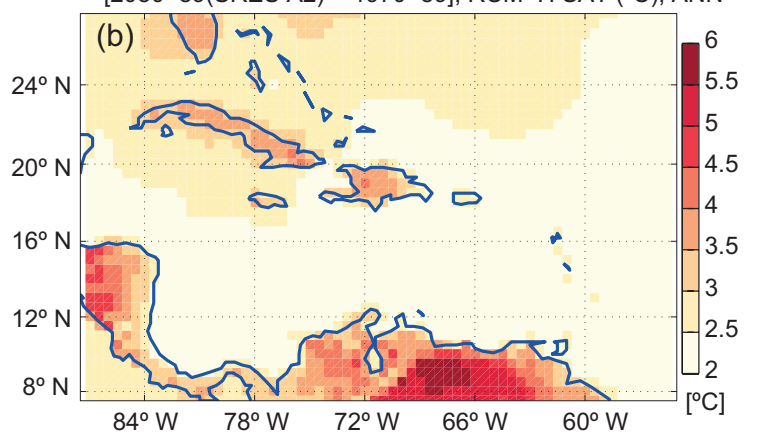

[2080-89(SRES A2) - 1970-89], RCM-E SAT $\left({ }^{\circ} \mathrm{C}\right)$, ANN

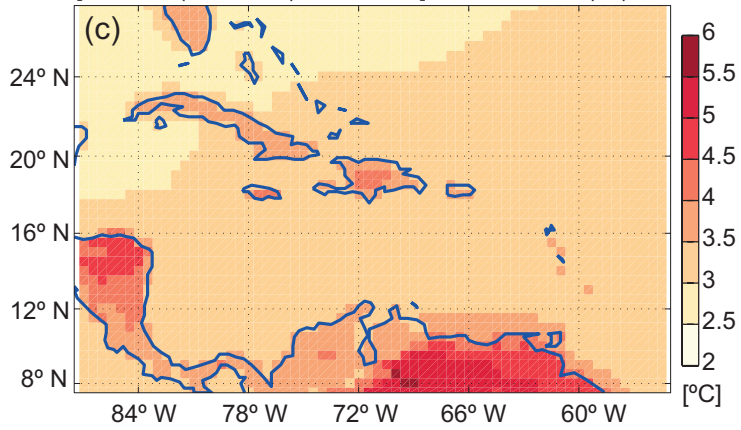

Fig. 8. Projected change in mean annual surface air temperature $\left({ }^{\circ} \mathrm{C}\right)$ by the 2080 s under the SRES A2 scenario in (a) CMIP3 multi-model ensemble, (b) RCM-H and (c) RCM-E. Projected change by the 2080s is relative to the mean climate of 1970-1989. In (a) for every grid box, the color indicates ensemble mean projection, the value at the center indicates ensemble median projection and values at the bottom-left and top-right corners indicate ensemble minimum and maximum projections, respectively.

for the island nations using the model data and other sources. The CMIP3 models underestimate the present day precipitation of the islands of the Caribbean. This might be attributable to their inability to resolve the smaller islands, particularly in the eastern Caribbean. However, since many of the CMIP3 models also fail to capture or severely underestimate the first peak in the bimodal precipitation signal, and this early season maximum is primarily a feature of the larger islands of the western Caribbean region, it suggests other deficiencies. Though we do not discuss it in this paper, the models seem to generally underestimate local SSTs and in particular the early onset of the Atlantic warm pool (Wang, 2007) in the western Caribbean. The models do however capture the late season maximum of SST as well as the annual cycles of local SLP and the CLLJ-two other important drivers of Caribbean climate - and so correctly time the occurrence of the late season maximum in Caribbean rainfall. On the other hand, the PRECIS RCM simulations show varied performance with one mostly overestimating precipitation and the other underestimating it in the wet season. The uncertainties in the driving models are seemingly responsible for some 
of the precipitation biases. The Hadley driven RCM, however, does capture the bimodal nature of the precipitation cycle in the western Caribbean (Cuba, Hispaniola and Jamaica), which makes a case for added value by the RCM (Campbell et al., 2010). Yet, even for the RCM, with its better resolution, there is some difficulty in capturing the seasonal precipitation variability in the region.

With respect to surface air temperatures, the CMIP3 models display a cold bias for all the small islands that are not resolved in the coarse-resolution but a warm bias for the larger islands that are resolved. The RCM simulations show a warm bias across the entire region, especially the eastern Caribbean islands which are better resolved.

The end of century picture of Caribbean climate, as deduced from the CMIP3 models is one characterized by a decrease in wet season precipitation. The decrease is generally higher for the early wet season than the late wet season and for the western Caribbean than the eastern Caribbean. The intense early season drying tends to smooth out the bimodality of the western Caribbean, but the seasonal cycle of the eastern Caribbean remains unchanged. The dry season is largely unaltered except for a small increase in precipitation in November in the Bahamas. The RCM simulations similarly project a drying (though more intense) for the wet season but the agreement between the two RCM projections is generally poor with respect to which portion (early or late) will be driest. Both the GCMs and the RCM project higher warming of surface air temperatures over the northwestern Caribbean and relatively lower warming in the southeastern Caribbean. The RCMs however have higher warming values in general, especially over the eastern Caribbean where the landmasses are better resolved.

In addition to the results above, a few other things bear noting. Firstly, most regions in the Caribbean present a bimodal seasonal cycle of precipitation, which results from the interaction between the NASH, the CLLJ, regional wind shear, local divergence, subsidence and the upper level atmospheric dynamics (Gamble and Curtis, 2008). Capturing of the cycle is a useful determinant of model or dataset suitability for use in the Caribbean since it would also suggest that the regional driving forces are also being reasonably captured. Equally important, then, is being able to accurately characterize the bimodality. Future work must include an examination of daily data, both observed and simulated, to determine, for example, the exact timing of the onset and end of the wet season and the duration of the MSD. This information is also vital for water resource management and agricultural activities in the region. We also note that whereas many of the physical processes affecting climate of the Caribbean are well studied and documented in the literature, easterly waves are not well discussed in the context of their significant contribution to Caribbean rainfall. There is need for further investigation of easterly waves in both current and future climates.

Secondly, although the GCM precipitation projections span a very wide range across the ensemble, most GCMs project a decrease in precipitation under the SRES A2 scenario by the 2080s. This drying is thought to be related to several interdependent factors such as expansion and intensification of the NASH (Rauscher et al., 2008), an increase in wind speeds over the Caribbean Sea (Cook and Vizy, 2010; Taylor et al., 2011, 2012), SST warming in the tropical North Atlantic (Rauscher et al., 2011), and a decrease in precipitation in regions along the margins of convective areas in the tropics (Chou and Neelin, 2004; Neelin et al., 2006). The RCM used in this study gives very different results when driven by boundary conditions from two different GCMs. This highlights the need to use an ensemble of model simulations that provide a range of projections taking into account various modeling uncertainties. Such a setup is now available for the RCM used in this study (McSweeney et al., 2012). Since the study also points out that the higher resolution of 
the RCM $(50 \mathrm{~km})$ is still not sufficient to resolve many small islands in the Caribbean, the suite of models should include some with $10 \mathrm{~km}$ or better resolution to fully resolve the smallest islands.

Thirdly, the performance of the individual GCMs included in the ensemble is not taken into account while calculating the ensemble mean. The ensemble mean and median have been shown to match observations better than any individual models (Gleckler et al., 2008), but using equal weights in ensemble mean calculations is problematic due to intermodel relationships (Masson and Kuntti, 2011). A worthwhile exercise would be to evaluate individual models in the region before using them for projections. Rigorous model evaluation however requires reliable observed data. Gridded observed (station and satellite) precipitation products used in this study show several disagreements (also shown in Jury, 2009); therefore making model evaluation challenging.

Fourthly, interannual variations in the seasonal cycle of climate parameters described above are large in the Caribbean, mainly resulting from climate variability in the eastern Pacific and the North Atlantic (Enfield and Alfaro, 1999; Giannini et al., 2000, 2001; Chen and Taylor, 2002; Taylor et al., 2002; Jury et al., 2007). El Niño Southern Oscillation (ENSO) (Enfield and Alfaro, 1999; Giannini et al., 2000; Taylor et al., 2002; Gouirand et al., 2012) and the North Atlantic Oscillation (Charlery et al., 2006; Jury et al., 2007; Gouirand et al., 2012) have seasonally dependent influence on temperature and precipitation. Changes, then, in ENSO and NAO variability in the future will affect climate variability in the Caribbean. The regional model PRECIS performed reasonably well in capturing the interannual variability in Central American temperature because the baseline simulations used observed SSTs as the surface boundary conditions and therefore a realistic ENSO forcing (Karmalkar et al., 2011). However, the global climate models used in this study show a varying degree of performances when tested for their ability to capture ENSO variations and disagree significantly on its future behavior (AchutaRao and Sperber, 2006). Studies that suggest a perpetual El Niño-like state for the Pacific in the future (Vecchi et al., 2006; Vecchi and Soden, 2007; DiNezio et al., 2009) are consistent with a summer drying in the Caribbean. However, the nature of ENSO and NAO variations in response to elevated levels of GHGs remains highly uncertain and is a limitation to examining future changes in interannual variability of Caribbean climate.

Finally, although the RCM simulations add regional detail to climate simulations produced by the GCMs in this region, the RCMs use dynamical downscaling techniques making their performance critically dependent on the quality of the driving GCM. These results indicate that, for spatial scales in question, improvements in model physics may contribute perhaps as much to our understanding of climate of the Caribbean as dynamical downscaling to $50 \mathrm{~km}$ resolution. For example, considering the major influence of SSTs on the climate of the Caribbean and on simulated precipitation, accurate representation of SSTs in the models could improve their performance. The dynamical downscaling using PRECIS RCM uses prescribed SSTs, but a model set-up in which SSTs are allowed to dynamically interact with and respond to changes in the overlaying atmosphere has been shown to perform better at simulating precipitation in other parts of the world (Artale et al., 2009; Ratnam et al., 2009). Such RCM studies are, however, non-existent for the Caribbean region.

\section{Acknowledgement}

This study was supported by the Caribsave partnership. We would also like to thank Caribbean Community Climate Change Centre (CCCCC) and the UK Met Office Hadley Centre for their 
contributions to the modeling efforts in the region. We thank Gil Lizcano and Carol McSweeney for their help with data management and processing.

\section{References}

AchutaRao K. M. and K. R. Sperber, 2006. ENSO simulation in coupled ocean-atmosphere models: Are the current models better? Clim. Dyn. 2, 1-15, doi:10.1007/s00382-006-0119-7.

Amador J. A., 2008. The Intra-Americas sea low-level jet: Overview and future research. Annal. N.Y. Acad. Sci. 1146, 153-188.

Amarakoon D. A., A. A. Chen, S. C. Rawlins, M. A. Taylor and D. D. Chadee, 2006. Retrospective study. In Climate change impact on dengue: The Caribbean experience. (A. A. Chen, D. D. Chadee and S. Rawlins, eds.). Mona, Jamaica: University of the West Indies, Climate Studies Group Mona, 66-77.

Ángeles M. E., J. E. González, D. J. Erickson III, J. L. Hernández, 2007. Predictions of future climate change in the Caribbean region using global general circulation models. Int. J. Clim. 27, 555-569, doi:10.1002/joc. 1416.

Artale V. S., A. C. Calmanti, A. Dell'Aquila, M. Herrmann, G. Pisacane, P. M. Ruti, G. Sannino, M. V. Struglia, F. Giorgi, X. Bi, J. S. Pal, S. Rauscher and The PROTHEUS Group, 2009. An atmosphere ocean regional climate model for the Mediterranean area: Assessment of a present climate simulation. Clim. Dyn. 35, 721-740, doi:10.1007/s00382-009-0691-8.

Biasutti M., A. H. Sobel, S. J. Camargo and T. T. Creyts, 2012. Projected changes in the physical climate of the Gulf coast and Caribbean. Climatic Change 112, 819-845.

Campbell J. D., M. A. Taylor, T. S. Stephenson, R. A. Watson and F. S. Whyte, 2010. Future climate of the Caribbean from a regional climate model. Int. J. Clim. 31, 1866-1878, doi:10.1002/joc.2200.

Cashman A., L. Nurse and J. Charlery, 2010. Climate change in the Caribbean: The water management implications. The Journal of Environment \& Development 19, 42-67.

Castro D. M., R. P. da Rocha, A. Benzanilla-Morlot, L. Álvarez-Escudero, J. P. Reyes-Fernández, Y. Silva-Vidal and R. W. Arritt, 2006. Sensitivity studies of the RegCM3 simulation of summer precipitation, temperature and local wind field in the Caribbean region. Theor. Appl. Climatol. 86, 5-22, doi:10.1007/s00704-005-0201-9.

Centella A., A. Bezanilla and K. Leslie, 2008. A study of the uncertainty in future Caribbean climate using the PRECIS regional climate model. Technical report. Belmopan, Belize: Caribbean Community Climate Change Centre (CCCCC).

Chan S. C., V. Misra and H. Smith, 2011. A modeling study of the interaction between the Atlantic warm pool, the tropical Atlantic easterlies, and the Lesser Antilles. J. Geophys. Res. 116, D00Q02, doi:10.1029/2010JD015260.

Charlery, J., L. Nurse and K. Whitehall, 2006. Exploring the relationship between the North Atlantic Oscillation and rainfall patterns in Barbados. Int. J. Clim. 26, 819-827.

Charlery J. and A. Nurse, 2010. Areal downscaling of global climate models: an approach that avoids data remodeling. Clim. Res. 43, 241-249, doi:10.3354/cr00875.

Chen A. A. and M. A. Taylor, 2002. Investigating the link between early season Caribbean rainfall and the El Niño+1 year. Int. J. Climatol. 22, 87-106.

Chen A. A., D. D. Chadee and S. Rawlins (eds.), 2006. Climate change impact on dengue: The Caribbean experience. Mona, Jamaica: Climate Studies Group Mona, University of the West Indies. 
Chen. A., M. Taylor, A. Centella and D. Farrell, 2008. Climate trends and scenarios for climate change in the insular Caribbean: Report of Working Group I, Climate Change and Biodiversity in the Insular Caribbean. CANARI Technical Report No. 381. Trinidad, W.I.: Caribbean Natural Resources Institute, $63 \mathrm{pp}$.

Chou C. and J. D. Neelin, 2004. Mechanisms of global warming impacts on regional tropical precipitation. J. Clim. 17, 2688-2701.

Church J. A., N. White, R. Coleman, K. Lambeck and J. Mitrovica, 2004. Estimates of regional distribution of sea level rise over the 1950-2000 period. J. Clim. 17, 2609-2625.

Comarazamy D. E. and J. E. González, 2008. On the validation of the simulation of early season precipitation on the island of Puerto Rico using a mesoscale atmospheric model. J. Hydrometeor. 9, 507-520.

Cook K. and E. Vizy, 2010. Hydrodynamics of the Caribbean low-level jet and its relationship to precipitation. J. Clim. 23, 1477-1494.

Dai A., 2006. Precipitation characteristics in eighteen coupled climate models. J. Clim. 19, 4605-4630.

DiNezio P., A. Clement, G. A. Vecchi, B. J. Soden, B. Kirtman and S. K. Lee, 2009. Climate response of the equatorial Pacific to global warming. J. Clim. 22, 4873-4892.

Donner S. D., T. R. Knutson and M. Oppenheimer, 2007. Model-based assessment of the role of human-induced climate change in the 2005 Caribbean coral bleaching event. Proc. Natl. Acad. Sci. U.S.A. 104, 5483-5488.

Ebi, K. L., N. D. Lewis and C. Corvalán, 2006. Climate variability and change and their potential health effects in small island states: Information for adaptation planning in the health sector. Environ. Health Perspect. 114, 1957-1963.

Enfield D. B. and E. J. Alfaro, 1999. The dependence of Caribbean rainfall on the interaction of the tropical Atlantic and Pacific oceans. J. Clim. 12, 2093-2103.

Fish M. R., I. M. Cote, J. A. Gill, A. P. Jones, S. Renshoff and A. Watkinson, 2005. Predicting the impact of sea level rise on Caribbean sea turtle nesting habitat. Conserv. Biol. 19, 482-491.

Frich P., L. V. Alexander, P. Della-Marta, B. Gleason, M. Haylock, A. M. G. Klein Tank and T. Peterson, 2002. Observed coherent changes in climatic extremes during the second half of the twentieth century. Clim. Res. 19, 193-212.

Gamble D. W. and S. Curtis, 2008. Caribbean precipitation: review, model and prospect. Prog. Phys. Geo. 32, doi:10.1177/0309133308096027.

Giannini A., Y. Kushnir Y and M. A. Cane, 2000. Interannual variability of Caribbean rainfall, ENSO, and the Atlantic Ocean. J. Clim. 13, 297-311.

Giannini A., Y. Kushnir and M. A. Cane, 2001. Seasonality in the impact of ENSO and the North Atlantic high on Caribbean rainfall. Phys. Chem. Earth Part B 26, 143-147.

Gleckler, P. J., K. E. Taylor and C. Doutriaux, 2008. Performance metrics for climate models, J. Geophys. Res. 113, D06104, doi:10.1029/2007JD008972.

Gouirand I., M. R. Jury and B. Sing, 2012. An analysis of low- and high-frequency summer climate variability around the Caribbean Antilles. J. Clim. 25, 3942-3952.

Graham N. E. and T. P. Barnett, 1987. Sea surface temperature, surface wind divergence, and convection over tropical oceans. Science 238, 657-659.

Granger O. E., 1985. Caribbean climates. Prog. Phys. Geog. 9, 16-43.

Hoegh Guldberg O., P. J. Mumby, A. J. Hooten, R. S. Steneck, P. Greenfield, E. Gomez, C. D. Harvell, P. F. Sale, A. J. Edwards, K. Caldeira, N. Knowlton, C. M. Eakin, R. Iglesias-Prieto, 
N. Muthiga, R. H. Bradbury, A. Dubi and M. E. Hatziolos, 2007. Coral reefs under rapid climate change and ocean acidification. Science 318, 1737-1742.

Huffman G. J., R. F. Adler, D. T. Bolvin, G. Gu, E. J. Nelkin, K. P. Bowman, Y. Hong, E. F. Stocker and D. B. Wolff, 2007. The TRMM multisatellite precipitation analysis (TMPA): Quasi-global, multiyear, combined-sensor precipitation estimates at fine scales. J. Hydrometeorol. 8, 38-55.

IPCC, 2000. Special report on emissions scenarios. A special report of Working Group III of the Intergovernmental Panel on Climate Change. Cambridge: Cambridge University Press, 599 pp.

IPCC, 2007. Climate change 2007: The physical science basis. Contribution of Working Group I to the Fourth Assessment Report of the Intergovernmental Panel on Climate Change (S. Solomon, D. Qin, M. Manning, Z. Chen, M. Marquis, K. B. Averyt, M. Tignor and H. L. Miller, eds.). Cambridge: Cambridge University Press, 996 pp.

Jones R. G., M. Noguer, D. Hassell, D. Hudson, S. Wilson, G. Jenkins and J. Mitchell, 2004. Generating high resolution climate change scenarios using PRECIS (manual). Exeter, UK: Hadley Centre for Climate Prediction and Research Met Office, $40 \mathrm{pp}$.

Jury M. R., B. A. Malmgren and A. Winter, 2007. Sub-regional precipitation climate of the Caribbean and relationships with ENSO and NAO. J. Geophys. Res. 112, D16107, doi:10.1029/2006JD007541.

Jury M. R., 2009. An inter-comparison of observational, reanalysis, satellite, and coupled model data on mean rainfall in the Caribbean. J. Hydrometeorol. 10, 413-430.

Kalnay E., M. Kanamitsu, R. Kistler, W. Collins, D. Deaven, L Gandin, M. Iredell, S. Sana, G. White, J. Woollen, Y. Zhu, M. Chelliah, W. Ebisuzaki, W. Higgins, J. Janowiak, K. C. Mo, C. Ropelewski, J. Wang, A. Leetmaa, R. Reynolds, R. Jenne and D. Joseph, 1996. The NCEP/ NCAR 40-year reanalysis project. Bull. Amer. Meteor. Soc. 77, 437-470.

Karmalkar A. V., R. S. Bradley and H. F. Diaz, 2008. Climate change scenario for Costa Rican montane forests. Geophys. Res. Lett. 35, L11702, doi:10.1029/2008GL033940.

Karmalkar A. V., R. S. Bradley and H. F. Diaz, 2011. Climate change in Central America and Mexico: Regional climate model validation and climate change projections. Clim. Dyn. 37, 605-629, doi:10.1007/s00382-011-1099-9.

Leloup J. and A. Clement, 2009. Why is there a minimum in projected warming in the tropical North Atlantic Ocean? Geophys. Res. Lett. 36, L14802, doi:10.1029/2009GL038609.

Magaña V., J. A. Amador, S. Medina, 1999. The midsummer drought over Mexico and Central America. J. Clim. 12, 1577-1588.

Martin E. R. and C. Schumacher, 2011. The Caribbean low-level jet and its relationship to precipitation in IPCC AR4 models. J. Clim. 24, 5935-5950.

Masson D. and R. Knutti, 2011. Climate model genealogy. Geophys. Res. Lett. 38, L08703, doi:10.1029/2011GL046864.

Matsuura K. and C. J. Willmott, 2007a. Terrestrial air temperature: 1900-2006 gridded monthly time series (version 1.01).[Available at http://climate.geog.udel.edu/ climate/html_pages/ Global_ts_2007/README.global.t_ts_2007.html].

Matsuura K. and C. J. Willmott, 2007b. Terrestrial precipitation: 1900-2006 gridded monthly time series (version 1.01). [Available at http://climate.geog.udel.edu/ climate/html_pages/ Global_ts_2007/README.global.p_ts_2007.html].

McSweeney C. F., M. New, G. Lizcano and X. Lu, 2010. The UNDP Climate Change Country Profiles: improving the accessibility of observed and projected climate information for studies of climate change in developing countries. Bull. American. Met. Soc. 91, 157-166. 
McSweeney C. F., R. G. Jones and B. B. B. Booth, 2012. Selecting ensemble members to provide regional climate change information. J. Clim., doi: 10.1175/JCLI-D-11-00526.1.

Meehl G. A., C. Covey, T. Delworth, M. Latif, B. McAvaney, J. F. B. Mitchell, R. J. Stouffer and K. E. Taylor, 2007. The WCRP CMIP3 multi-model dataset: A new era in climate change research. Bull. American. Met. Soc. 88, 1383-1394.

Mimura N., L. Nurse, R. F. McLean, J. Agard, L. Briguglio, P. Lefale, R. Payet and G. Sem, 2007. Small islands. In: Climate change 2007: Impacts, adaptation and vulnerability. Contribution of Working Group II to the Fourth Assessment Report of the Intergovernmental Panel on Climate Change (M. L. Parry, O. F. Canziani, J. P. Palutikof, P. J. van der Linden and C. E. Hanson, eds.). Cambridge: Cambridge University Press, pp. 687-716.

Mitchell T. D., 2003. Pattern scaling: An examination of the accuracy of the technique for describing future climates. Climatic Change 60, 217-242.

Moore W. R., 2010. The impact of climate change on Caribbean tourism demand. Current Issues in Tourism 13, 495-505.

Muñoz E., A. J. Busalacchi, S. Nigam, A. Ruiz-Barradas, 2008. Winter and summer structure of the Caribbean low-level jet. J. Clim. 21, 1260-1276.

Naranjo-Díaz L. R. and A. Centella, 1998. Recent trends in the climate of Cuba. Weather 53, 8085, doi:10.1002/j.1477-8696.1998.tb03964.x.

Neelin J. D., M. Munnich, H. Su, J. E. Meyerson and C. E. Holloway, 2006. Tropical drying trends in global warming models and observations, doi:10.1073 pnas.0601798103.

Nelson G. C., M. W. Rosegrant, J. Koo, R. Robertson, T. Sulser, T. Zhu, C. Ringler, S. Msangi, A. Palazzo, M. Batka, M. Magalhaes, R. Valmonte-Santos, M. Ewing and David Lee, 2009. Climate change. Impact on agriculture and costs of adaptation. Food policy report. Washington, D.C.: International Food Policy Research Institute, 19 pp.

New M., D. Lister, M. Hulme and I. Makin, 2002. A high-resolution data set of surface climate over global land areas. Clim. Res. 21, 1-25, doi:10.3354/cr021001.

OECS, 2004. Grenada: Macro socio-economic assessment of the damages caused by hurricane Ivan. Castries, St. Lucia: Organisation of East Caribbean States, 139 pp.

Peterson T. C., M. A. Taylor, R. Demeritte, D. L. Duncombe, S. Burton, F. Thompson, A. Porter, M. Mejia, E. Villegas, R. Semexant Fils, A. Klein Tank, A. Martis, R. Warner, A. Joyette, W. Mills, L. Alexander and B. Gleason, 2002. Recent changes in climate extremes in the Caribbean region. J. Geophys. Res, 107, 4601, doi:10.1029/2002JD002251.

Pulwarty R. S., L. A. Nurse, U. O. Trotz, 2010. Caribbean islands in a changing climate. Environment: Science and Policy for Sustainable Development 52, 16-27.

Randall D. A., R. A. Wood, S. Bony, R. Colman, T. Fichefet, J. Fyfe, V. Kattsov, A. Pitman, J. Shukla, J. Srinivasan, R. J. Stouffer, A. Sumi and K. E. Taylor, 2007. Climate models and their evaluation. In: Climate change 2007: The physical science basis. Contribution of Working Group I to the Fourth Assessment Report of the Intergovernmental Panel on Climate Change (S. Solomon, D. Qin, M. Manning, Z. Chen, M. Marquis, K. B. Averyt, M. Tignor and H. L. Miller, eds.). Cambridge: Cambridge University Press, pp. 589-662.

Ratnam J., F. Giorgi, A. Kaginalkar and S. Cozzini, 2009. Simulation of the Indian monsoon using the RegcCM3-ROMS regional coupled model. Clim. Dyn. 33, 119-139.

Rauscher S., F. Giorgi, N. S. Diffenbaugh and A. Seth, 2008. Extension and intensification of the Meso-American mid-summer drought in the twenty-first century. Clim. Dyn. 31, 551-571, doi:10.1007/s00382-007-0359-1. 
Rauscher S., F. Kucharski and D. Enfield, 2011. The role of regional SST warming variations in the drying of Meso-America in future climate projections. J. Clim. 24, 2003-2016.

Rayner N. A., D. E. Parker, E. B. Horton, C. K. Folland, L. V. Alexander, D. P. Rowell, E. C. Kent and A. Kaplan, 2003. Global analyses of sea surface temperature, sea ice, and night marine air temperature since the late nineteenth century. J. Geophys. Res. 108, NO. D14, 4407, doi:10.1029/2002JD002670.

Reed W. W., 1926. Climatological data for the West Indian Islands. Mon. Wea. Rev. 54, 133-160.

Rudolf B. and U. Schneider, 2005. Calculation of gridded precipitation data for the global landsurface using in-situ gauge observations. Proceedings of the 2nd Workshop of the International Precipitation Working Group (IPWG), Monterey, EUMETSAT, 231-247.

Rudolf B., C. Beck, J. Grieser and U. Schneider, 2005. Global precipitation analysis products. Global Precipitation Climatology Centre (GPCC), Deutscher Wetterdienst (DWD), pp. 1-8 (Internet publication).

Schultz D. M., W. E. Bracken and L. F. Bosart, 1998. Planetary- and synoptic-scale signatures associated with Central American cold surges. Mon. Weather Rev. 126, 5-27.

Simpson M. C., D. Scott, M. Harrison, R. Sim, N. Silver, E. O’Keeffe, S. Harrison, M. Taylor, G. Lizcano, M. Rutty, H. Stager, J. Oldham, M. Wilson, M. New, J. Clarke, O. J. Day, N. Fields, J. Georges, R. Waithe and P. McSharry, 2010. Quantification and magnitude of losses and damages resulting from the impacts of climate change: Modelling the transformational impacts and costs of sea level rise in the Caribbean (full document). Barbados, West Indies: United Nations Development Programme (UNDP).

Singh B., 1997. Climate changes in the greater and southern Caribbean. Int. J. Clim. 17, 10931114.

Small R. J. O., S. P. de Szoeke and S. P. Xie, 2007. The Central American midsummer drought: Regional aspects and large-scale forcing. J. Clim. 20, 4853-4873.

Smith, R. B., P. Schafer, D. J. Kirshbaum and E. Regina, 2009. Orographic precipitation in the tropics: Experiments in Dominica. J. Atmos. Sci. 66, 1698-1716.

Sobel A. H., C. D. Burleyson and S. E. Yuter, 2011. Rain on small tropical islands. J. Geophys. Res. 116, D08102, doi:10.1029/2010JD014695.

Spence J. M., M. A. Taylor and A. A. Chen, 2004. The effect of concurrent sea surface temperature anomalies in the tropical Pacific and Atlantic on Caribbean rainfall. Int. J. Clim. 24, 1531-1541, doi:10.1002/joc.1068.

Stephenson T. S., A. A. Chen and M. A. Taylor, 2007. Toward the development of prediction models for the primary Caribbean dry season. Theor. Appl. Climatol. 92, 87-101, doi:10.1007/ s00704-007-0308-2.

Taylor M.A., D. B. Enfield and A. A. Chen, 2002. The influence of the tropical Atlantic $v s$. the tropical Pacific on Caribbean rainfall. J. Geophys. Res. 107, NO. C9 3127, doi:10.1029/2001JC001097.

Taylor M. A. and E. J. Alfaro, 2006. Climate of Central America and the Caribbean. In: Encyclopedia of World Climatology (J. E. Oliver, ed.). Springer.

Taylor M. A., A. A. Chen and W. Bailey, 2009. Review of health effects of climate variability and climate change in the Caribbean. Technical Report. Belmopan, Belize: Caribbean Community Climate Change Centre (CCCCC).

Taylor M. A., T. S. Stephenson, A. Owino, A. A. Chen and J. D. Campbell, 2011. Tropical gradient influences on Caribbean rainfall. J. Geophys. Res., doi:10.1029/2010JD015580 
Taylor M. A., F. S. Whyte, T. S. Stephenson and J. D. Campbell, 2012. Why dry? Investigating the future evolution of the Caribbean low-level jet to explain projected Caribbean drying. Int. J. Climatol., doi:10.1002/joc.3461.

Vecchi G. A., B. J. Soden, A. T. Wittenberg, I. M. Held, A. Leetmaa and M. J. Harrison, 2006. Weakening of the tropical Pacific atmospheric circulation due to anthropogenic forcing. Nature 441, 73-76, doi:10.1038/nature04744.

Vecchi G. A. and B. J. Soden, 2007. Global warming and the weakening of the tropical circulation. J. Clim. 20, 4316-4340, doi:10.1175/ JCLI4258.1.

Wang C., 2007. Variability of the Caribbean low-level jet and its relations to climate. Clim. Dyn. 29, 411-422.

Wang C. and S. Lee, 2007. Atlantic warm pool, Caribbean low-level jet, and their potential impact on Atlantic hurricanes. Geophys. Res. Lett. 34, L02703, doi:10.1029/2006GL028579.

Wang C., S. K. Lee and D. B. Enfield, 2008. Climate response to anomalously large and small Atlantic warm pools during the summer. J. Clim. 21, 2437-2450.

Whyte F. S., M. A. Taylor, T. S. Stephenson and J. D. Campbell, 2008. Features of the Caribbean low-level jet. Int. J. Clim. 28, 119-128.

Xie P. and P. Arkin, 1997. Global precipitation: A 17 year monthly analysis based on gauge observations, satellite estimates, and numerical model outputs. Bull. Amer. Meteor. Soc. 78, 2539-2558. 